Historic, Archive Document

Do not assume content reflects current scientific knowledge, policies, or practices. 



\section{FUNK BROS. SEED CO.}

Bloomington, Illinois

22,000 Acres

Established 1824

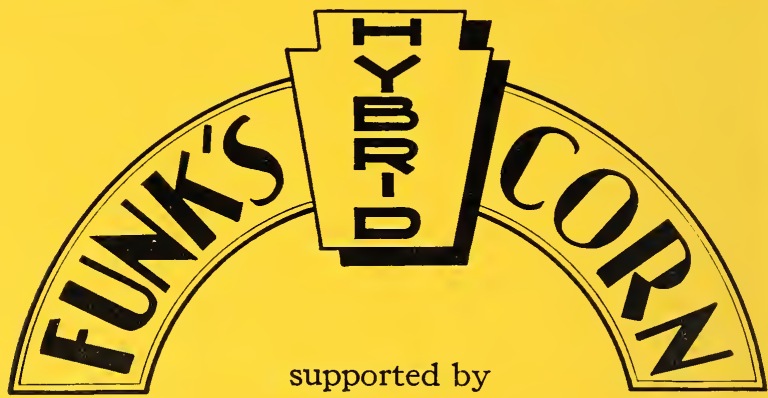

107 YEARS OF CORN GROWING

35 YEARS OF SCIENTIFIC BREEDING

16 YEARS OF HAND POLLINATION

TRUSTWORTHY THOUGHT OF

PRACTICAL SCIENTISTS

COSTLY LABOR OF HUNDREDS OF MEN

all these years and work are included in every kernel of

\section{Funk's Hybrid Corn}

the result is:

It does not cost you money

BUT MAKES YOU MONEY

YOU PAY LESS THAN FIVE CENTS PER BUSHEL FOR THE 10 TO 15 BUSHELS EXTRA YOU PRODUCE ON EACH ACRE

Funk's High Yielding Seed Corn 


\section{With a Fair Deal Agriculture Can and Will Recover}

1932 will probably go down in history as an outstanding year in Agriculture, where faith coupled with hard work and bulldog tenacity will win for the progressive farmer. For the past twelve years Agriculture has had to pass through a siege of depression under which no other industry could have survived.

Our farms may be a heavy burden during these depressing times, but they will not burn up nor become obsolete. Some changes are bound to take place. Perhaps someone else will occupy the farm where we are merely eking out an existence today. But every human being has to eat in order to live. Ard the substance which maintains life has to come largely from the soil.

It will be those who adhere to the principle of economic production of farm crops, WHO PLANT CLEAN, HIGH-YIELDING, STRONG-GERMINATING AND WELL-ADAPTED SEEDS THAT WILL SUCCEED.

Agriculture will never succeed under a strain of cheap, low-producing farm seeds.

Funk Bros. have been laboring for years to produce and handle those farm seeds that meet the requirements of the successful farmer.

We are endeavoring, all the while, to produce for next year a better lot of seed than we have ever handled before. Our aim is to give our customer something from which he can realize a profit from his own effort.

Our policy has never been to enter into competition with those who care little or nothing for the farmer except his dollars-who sell a cheap article because it is cheap and who can therefore undersell those who conscientiously adhere to a strict fulfillment of their promises and claims.

Our HYBRID strains of seed corn are our latest development in Corn Breeding-they are described in the following pages. The average results during the past six years from planting Funks Hybrid Seed proves that it costs less than five cents per bushel for the extra bushels that you produce.

The Illinois seed law defines Hybrid Corn.

"Hybrid seed corn, as the term is now commonly used, signifies seed resulting from cross fertilization involving inbred lines of corn or (and) their combinations; the inbred lines having been self-fertilized until they are reasonably pure." Illinois Seed and Weed Control Laws, Bulletin 330, Page 6.

We have reduced the price of Funks Hybrid Seed Corn this year because we have been able to lower the cost of production and we are giving our customers the benefit of these lower prices.

E. D. FUNK, President.

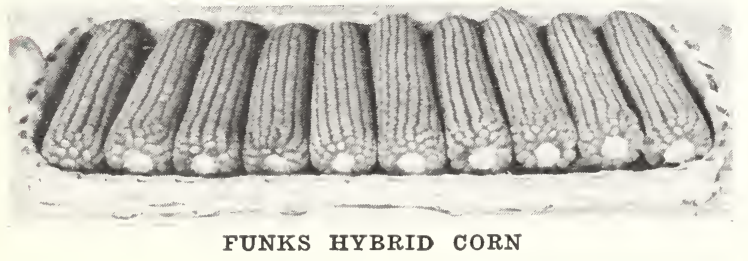




\section{FUNKS HYBRID 365}

Yellow Dent

Maturity 110-115 Days

One of the reports coming to us tells the story in a very few words:

"'sounder, better maturity, less disease, wind resistant, more vigorous, better yield.'

Hybrid 365 yielded 12 to 15 bushels per acre more than this man's own corn.

\section{INCREASE IN YIELD}

The increase in yield resulted because long careful breeding has eliminated barren stalks and increased resistance to cold, disease and drought.

\section{BIG RETURN ON INVESTMENT}

When one bushel of corn plants eight acres and the increase in yield due to this superior seed averages 12 bushels an acre, the price of the seed is of minor importance. When 96 bushels of corn is the direct return from one bushel of good seed corn, igure for yourself, at the prevailing market price, what a bushel of good seed corn is worth.

\section{SEED CORN PRICES ARE LOWER}

Funks Hybrid has been produced on a commercial scale for a number of years. We have learned something new each year and have been able to put more efficient practices into operation. As a result we are able to offer the same high quality seed at greatly reduced prices. Consult the enclosed price list. Take advantage of this opportunity to raise more bushels of corn.

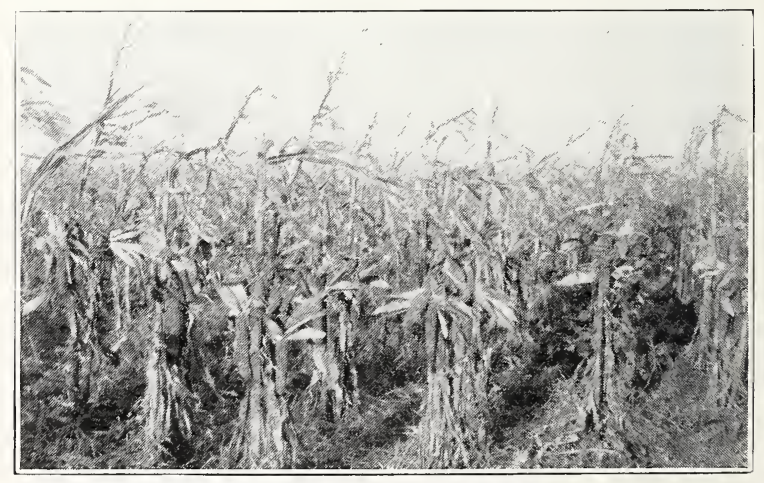

Photographed November 15

Ears-Ears-Ears, on Standing Stalks. That's Funks Hybrid Corn 


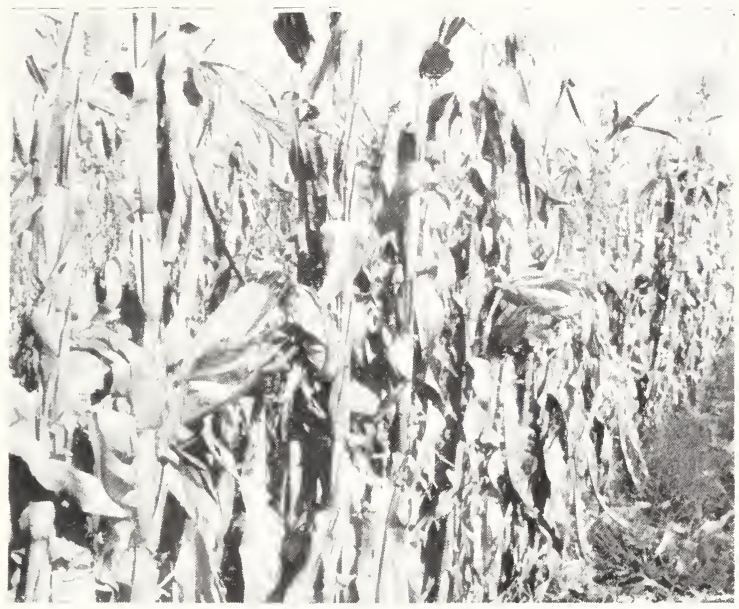

Funks Hybrid 365 is profitable

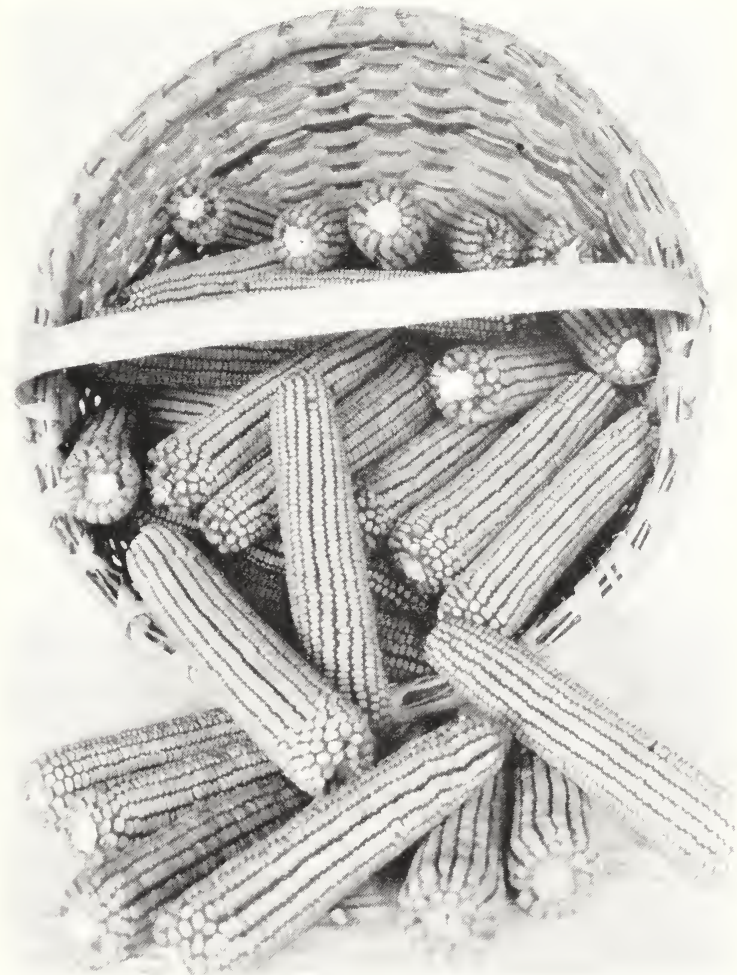

The increased yield obtained with FUNKS HYBRID CORN COSTS IESS THAN $5 \mathrm{c}$ per bushel. 


\section{FUNKS HYBRID 517}

Yellow Dent

Maturity 110 to 115 Days

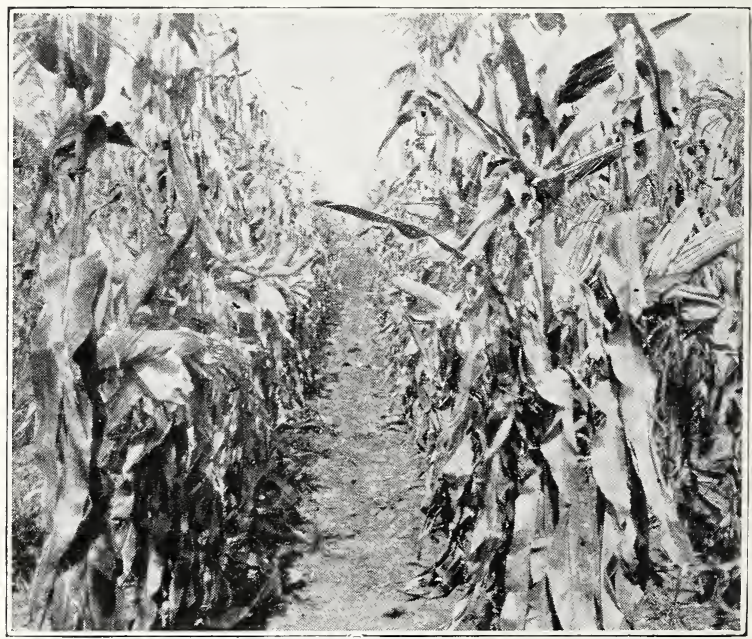

Funk's Hybrid No. 517 growing on the Funk Farms. Standing perfectly with a good ear on every stalk was a pleasing sight to behold.

Hybrid 517 has proven itself under actual farm conditions. Our confidence in 517 has increased each season and in addition many enthusiastic farmers have joined us in this belief.

\section{RANKS HIGH IN TEST PLOTS}

Besides coming through with fiying colors on farms throughout the Corn Belt, Hybrid 517 has passed numerous tests conducted by Farm Advisers, County Agents and other responsible parties.

\section{HYBRID 517 HAS ADVANTAGE}

Funks Hybrid 517 has the advantage over open-pollinated varieties of being more resistant to cold, disease and drought. It is more uniformly well rooted and stiff stalked. A good ear is found low down on each stalk. Hybrid 517 is considerably superior to open-pollinated varieties. Moreover, Hybrid 517 is a very easy corn to shuck.

\section{NEW LOW PRICES}

New low prices have been put into effect this season. Hybrid corn is several years beyond the experimental stage and now the low price of this high quality seed puts it within the reach of every farmer. This seed offers an opportunity for increased profit on your corn crop. Send in your order today. Convenient order blank enclosed. 


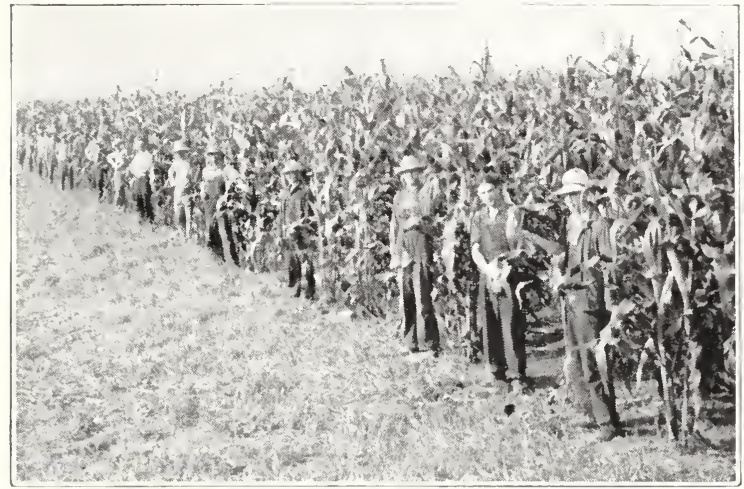

\section{A DETASSELLING CREW AT WORK ON} THE FUNK FARMS

Two strains of Inbred or Hybrid corn are planted systematically throughout a field, two rows of one strain and one row of another. The two rows of one strain are detasselled through the entire field so that all the pollen is produced by the cther strain. The parentage of Funk's Hybrid Corn is carefully controlled.

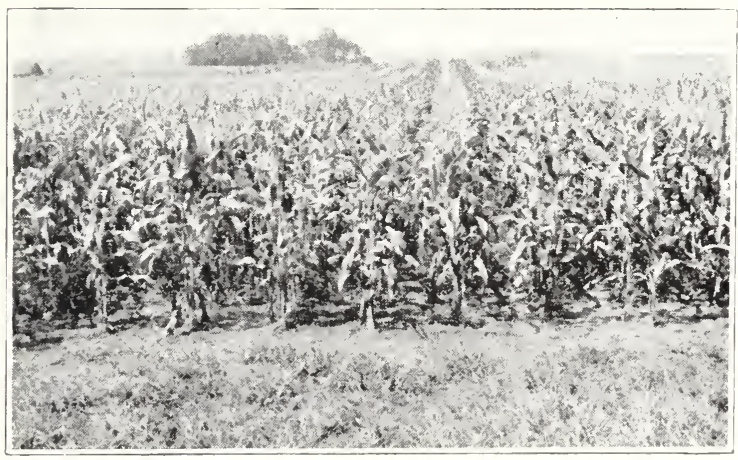

PRODUCING FUNK'S HYBRID CORN

Note the one pollinator row (tassels left on) and the two detasselled rows. Funk's Hybrid seed is harvested only from the detasselled rows.

An Added Convenience to the Man on the Planter FUNKS HYBRID SEED CORN is put up in special 1 bushel sealed bags. It is all shelled, graded, treated and ready for the planter box. Bags will be broken to suit your need, however, at the new low price of FUNKS HYBRID SEED CORN, one bushel should certainly be a minimum order. 


\section{FREE - FREE - FREE}

\section{Special on Quantity Orders of Funks Hybrid Seed Corn}

1-2 bu. Free with each $5 \mathrm{bu}$. order

$1 \mathrm{bu}$. Free with each $10 \mathrm{bu}$. order

$2 \mathrm{bu}$. Free with each $20 \mathrm{bu}$. order

5 bu. Free with each $50 \mathrm{bu}$. order

$10 \mathrm{bu}$. Free with each $100 \mathrm{bu}$. order

We make this special quantity offer on FUNKS HYBRID SEED CORN in order to encourage its use on larger acreages. Some of our customers buy as much as 1.00 bushels and many plant their entire acreage with this superior seed corn. They have tried it over a period of years and found it to pay a good return on the investment. It will do the same for you. At the NEW LOW PRICE you cannot afford to overlook FUNKS HYBRID CORN.

\section{LOWER}

PRODUCTION COST MEANS GREATER PROFIT

The keynote for agriculture in 1932 is lower production cost. Larger yield per acre is an immediate step toward lower cost of production. Lower production cost means greater profit. Use FUNKS HYBRID SEED CORN as a means of increasing your profits in 1932.

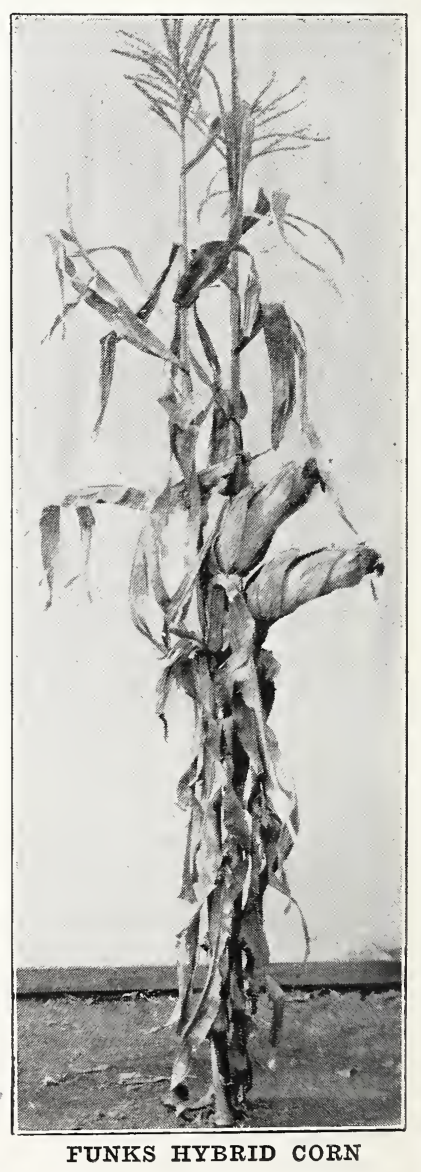

USE CONVENIENT ORDER BLANK TODAY 


\section{Funk Farms Facts}

North and South, East and West, Funks High Yielding Seed Corn yields the best.

Funk Bros. are the ORIGINAL and the MOST EXTENSIVE breeders of the HIGHEST YIELDING SEED CORN in the world.

Breeding for increased yields of quality corn is vastly different from the mere selection of fine looking ears.

The basis for the selection of Funks High Yielding Seed Corn are the scales for yield, standing ability of the stalks plus quality of grain.

It is an actual fact demonstrated by thousands of customers that an average increased yield of 15 bushels an acre may be had by planting Funks Hybrid Seed Corn.

It costs less than 5 cents a bushel to secure the 15 extra bushels an acre.

If it were a practical thing to do, we would gladly furnish the seed and take our pay from the yield increase knowing that we would get much more than the price that we charge for the seed.

By securing some of our highest yielding strains of corn each year, you can get the benefit of our breeding right up-to-date.

You might be interested to know that it requires over a million bushels of seed corn to plant the acreage of Illinois each year.

Our high yielding seed corn is packed and shipped only in our stamped bags and any seed corn offered as having come from Funk Bros. Seed Co. without having our regular stamp on the bag is not grown by us.

After reading the above, which is based on facts, can you hesitate to try one or more bushels of Funks High Yielding Seed Corn even though you have some fine looking early-picked corn from your own field?

\section{After All, It's Performance That Counts}

\section{TESTIMONIALS}

\section{SINNISSIPPI FARMS}

Oregon, Illinois, Sept. 28, 1931.

The corn I have raised from the bushel of Hybrid Seed you sent me last spring is the best I have ever raised. I planted it along side of some .............. which is rather generally raised throughout this country and I believe the Hybrid will go fifteen to twenty bushels to the acre more than the other.

LEE M. GENTRY, Manager.

Waterflow, New Mexico, Dec. 14, 1931. the results were marvelous. All my neighbors got some of this seed from my field and today you will find every crib in this beautiful San Juan Valley filled with this most wonderful corn. This is an irrigated valley and we produce from 85 to 115 bushels per acre. I feel that too much cannot be said for your corn. It has been worth many thousands of dollars to our valley. If our valley is indebted to you for thousands of dollars, what must the nation as a whole owe you? 


\section{Funks Yellow Dent}

Strain 176-A

Maturity 115-120 Days

"What is the best seed corn?" This question is the one asked us most frequently. Here is the answer. Funk's Yellow Dent is the best open-pollinated corn being grown today.

\section{PROGRESSIVE FARIERS RETURN TO FUNKS YELLOW DENT}

Thousands of progressive farmers and seedsmen throughout the Corn Belt, yes we can honestly say throughout the World, have put this corn to every test for the last fifteen years. Many have backed up. They have tried other varieties. The pleasing feature to us is that they returned to Funk's Yellow Dent.

\section{ORIGINAL UTILITY TYPE CORN}

Medium smooth indentation conforming to Utility Type standards. Deep kernels well filled to the tip and having a bright lustre.

Our seed ears were picked early, carefully dried and stored and each ear inspected before going to the sheller.

\section{QUALITY SEED PAYS DIVIDENDS}

This is the seed which gives the early vigor so necessary as a foundation for a good corn crop. Early vigor and final yield are closely related. We have spared no expense in breeding, selection and care so that you can have the high germination and vigor which result in more pounds of high quality marketable corn per acre.

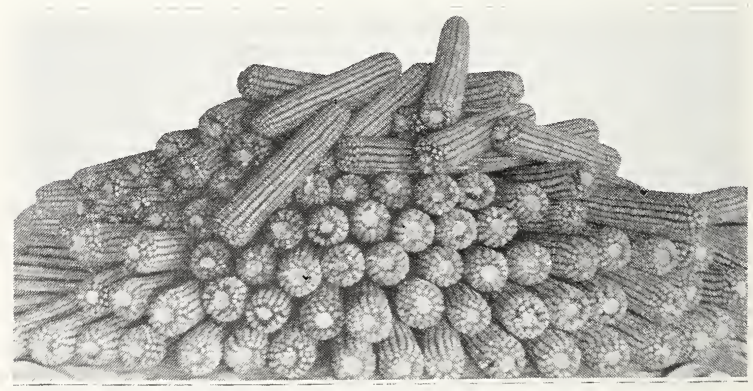

Funks Yellow Dent, Strain 176A is a profitable corn to grow.

SEE SPECIAL ANNOUNCEMENT PAGES 16 and 17. 


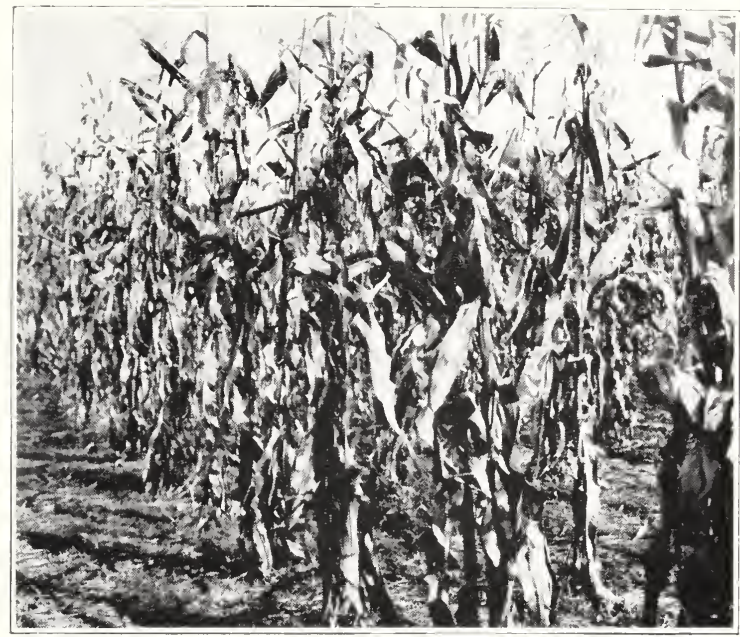

FUNK'S YELLOW DENT, standing and well eared. This is the original Utility Type Corn. It is ever gaining friends and proving itself under actual farm conditions.

\section{Silvermine}

\section{0-115 Days}

Funk's Silvermine is a medium early white dent. Ears are cylindrical, medium circumference, 9 to 11 inches long, and the deep broad creamy white kernels are a favorite with the Hominy Miller.

\section{PREMIUM ON WHITE CORN}

The premiums being paid for white corn is increasing the demand for Silvermine, so place your order early before the supply is exhausted.

\section{Gold Standard Leaming}

Maturity 115-120 Days

This variety was originated by $\mathrm{Mr}$. J. S. Leaming of Wilmington, Ohio, about 1826. It is one of the oldest varieties on the market at the present time.

The ears are medium to large and have a rich golden color, very characteristic of this variety.

WE TEST SEED CORN FOR FARMERS BY MAIL. SEE PAGE 13. NEW LOW PRICE OF $\$ 1.50$ FOR EACH 100 EARS. 


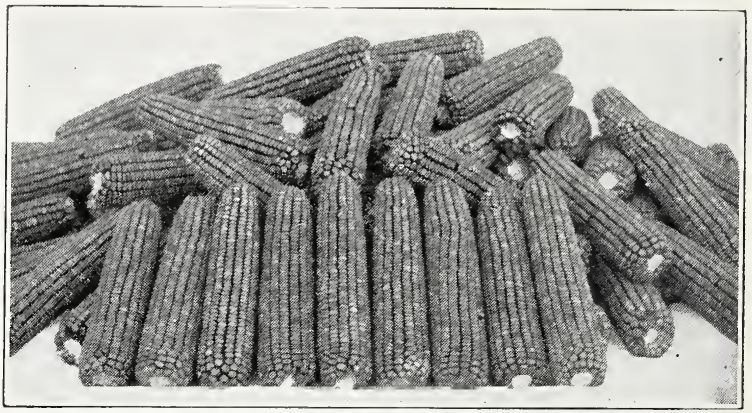

FUNK'S 100 DAY YELLOW DENT

A high yielding early corn. Broad, deep, oily kernels give it a high quality feeding corn.

\section{Funks 100 Day Yellow Dent Strain 329 100 Day Maturity}

"HIGH FEEDING VALUE', characterizes this corn and makes it an outstanding favorite with the cattle and hog feeder. The broad deep oily kernels and the general high quality of the grain are the characters so pleasing to the feeder. In short, this corn puts on pounds when fed to livestock.

\section{EARLINESS AND YIELD}

Funks 100 Day Yellow Dent fills a very definite need for a strain which combines earliness, and its attending quality, with yield. One bushel of good quality well matured corn is worth two bushels of a later, starchy, immature variety.

\section{GOOD BOTTOM LAND CORN}

Strong vigorous stalks of medium height combined with a sturdy root system gives Funks 100 Day the standing qualities to make it a good corn for the picker. We also recommend this strain for bottom land where planting is often delayed and where early frosts often occur.

\section{FUNKS 329 INCREASINGLY POPULAR}

High Yielding, Good Quality, Standing Ability. What more could you ask for in an open-pollinated variety? One farmer came to our warehouse last spring with a truck and took out over 75 bushels of this seed for himself and his neighbors.

Funks 100 Day started in this community with one small order several years ago. We offer this as a concrete example of the increasing popularity of this corn; a popularity which has been built up on actual farm performance.

SEED MORE LEGUMES FOR FORAGE AND FERTILITY. 


\section{PROPER STORAGE INSURES FUNKS SEED CORN}

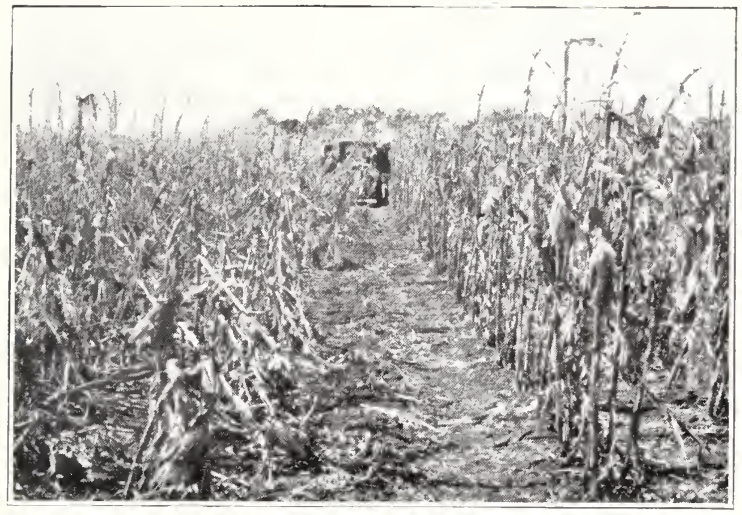

Seed stored in unheated building. Cold temperature took its toll. Funk's methods eliminate such results. Make sure that seed corn you purchase has been properly handled and cared for.
This seed was picked early. It was carefully dried and stored in a warehouse where the temperature was never below freezing. THIS IS WHAT YOU GET IN FUNKS HIGH YIELDING SEED CORN.

\section{KRUG}

\section{Yellow Dent}

105-110 Days

Krug is a variety which had its origin in Woodford County which adjoins our county of McLean on the north. It is the result of many years of careful selection for a deep kernel and weighty ears.

Krug is one of the popular open-pollinated Corn Belt varieties today and is giving a good account of itself over a wide range of conditions.

The seed we are offering conforms to the true Krug type. It was grown on the Funk Farms from disease free seed and is of excellent quality.

\section{SORGHUM}

For Molasses or Fodder

Early Black Amber Syrup Cane Grown from Select Unmixed Seed

Here it is. Real old fashioned sorghum and a real molasses maker. Good on hot cakes, bread, mush and a dozen other ways. Molasses offers many farmers another source of cash income. Here is the way to make a good profit on a part of your land.

Sorghum is also used for fodder and we find that there is an increasing demand for this rich feed.

You will find that we have a good quality of clean, unmixed seed. It is true to type and free from weeds or other contamination. Only a small supply of this seed is available and we suggest an early order. 


\section{Funk's 90-Day Yellow Dent}

\section{Maturity About 90 Days}

A standard early corn since 1892, Funk's 90 Day has been bred and grown since that time under the direct supervision of Mr. E. D. Funk.

The ears are from 7 to 9 inches long and from 6 to 7 inches in circumference, having 14 to 18 rows of kernels. The grain is of bright golden color, deep, oily and of high quality. Funk's 90 Day has the stiffness of stalk and ruggedness of root system to give it fine standing ability.

Funk's 90 Day has sufficient cold resistance in the Spring to make it adapted for early spring planting. It has no superior as an early maturing, high yielding corn for hogging down. Planted early, Funk's 90 Day often matures for feeding purposes by the last half of August.

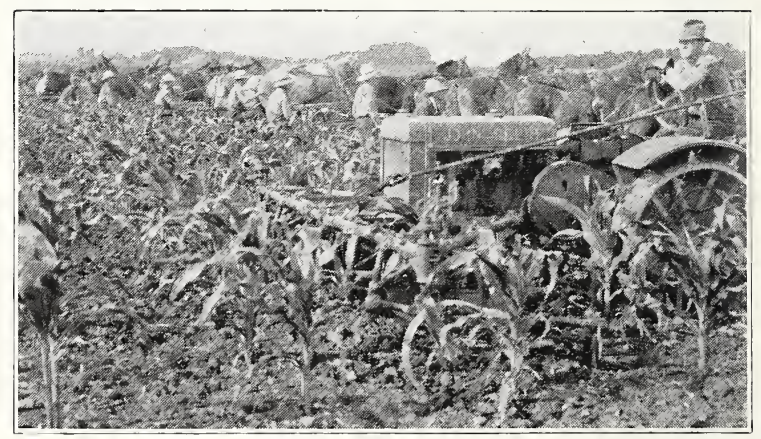

Corn cultivation is an important operation. This shows a part of the gang on the Funk Farms. Several types of cultivators have been found successful when properly adjusted.

\section{Bloody Butcher}

This is a white-capped, 90 Day red corn. If you want an early corn to hog down, Bloody Butcher will fill the bill exactly. Above all, Bloody Butcher will produce pork. It can be grown successfully anywhere in the Corn Belt.

DON'T FAIL TO SEE SPECIAL ANNOUNCEMENT ON PAGES 16 AND 17. 


\section{Let Us Test Your Corn By Mail}

The efficient methods, expert workmanship and modern equipment of the largest and oldest seed corn testing laboratory in the world is right at your mail box. This is the most economical means you can use to obtain the benefits of your own TESTED SEED CORN.

\section{\$1.50 FOR TESTING 100 EARS}

\section{ONLY 25c AN ACRE FOR TESTED SEED CORN}

You send six kernels from each ear to us in numbered envelopes which we furnish. A numbered tab, to be placed on the ear, accompanies each numbered envelope. The germination record is returned to you on a sheet which is numbered to correspond to the ears you sent us.

The corn never leaves your farm. No expensive transportation charges. No chance for a mixup.

WRITE FOR SPECIAL CIRCULAR GIVING DE-

TAILED PHOTOGRAPHIC EXPLANATION.

LET US KNOW HOW MANY EARS YOU

WISH TO HAVE TESTED AND

NUMBERED ENVELOPES WILL

BE SENT AT ONCE.

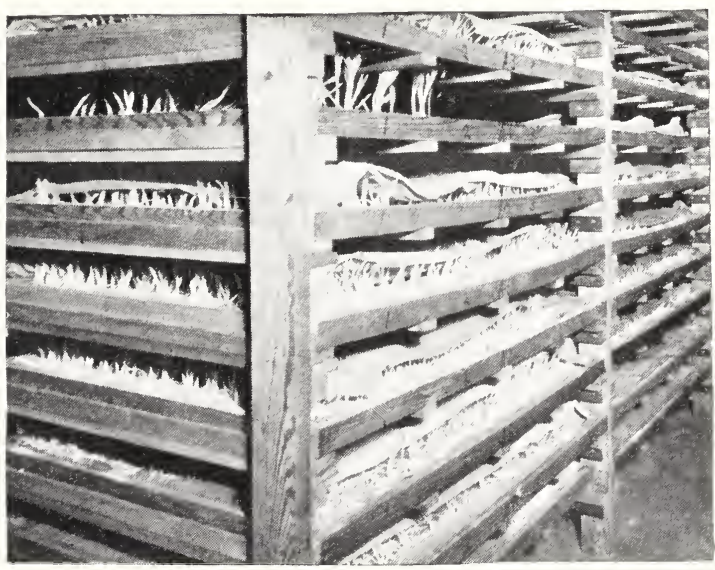

A corner of our large germinator where good corn gets its start

Clover And Alfalfa Prices Are Reasonable 


\section{Speed Up Your Seed Preparation With Funks Improved Nubber}

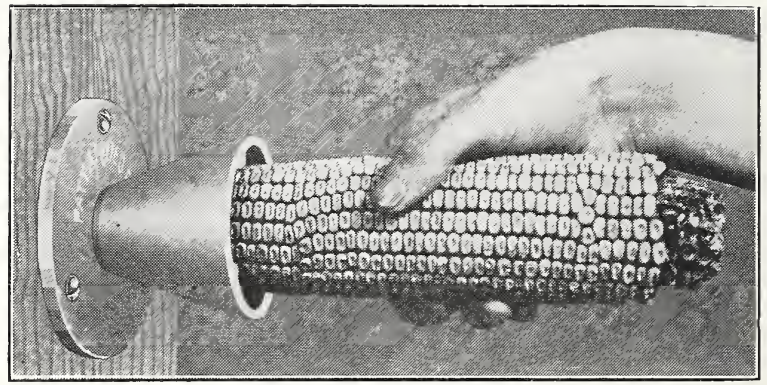

\$.75 Each, Postpaid

The cost is low. Savings in time are worth much more than you pay for this simple device. It prevents sore hands and worn out gloves. Speed up the most tiresome part of seed corn preparation, butting and tipping the ears.

\section{Reid's Yellow Dent}

\section{0-120 Days}

The ears are 8 to 11 inches long, 7 to 8 inches in circumference, 18-22 rows of kernels, each row containing 50 to 60 kernels. The cob is small and carries a large amount of corn which insures a high shelling percent.

This old standard Yellow Dent is unapproachable as a yielder. By continued selection we have eliminated the rough starchy ears until at the present time it conforms to Utility Type Standards.

We are fortunate indeed in having a small lot of high quality seed of this old favorite. Place your order early before this lot is sold out.

\section{TESTIMONIALS}

INTERNATIONAI HARVESTER CO.

Chicago, Illinois, June 10, 1931.

Wherever I go I find that your name is about as well known as that of Luther Burbank. It is a wonderful thing to have contributed so much to the improvement of America's greatest crop, corn.

$$
\text { P. G. HOLDEN, Field Director. }
$$

STAR GRAIN CO.

Chicago, Illinois, Sept. 28, 1931.

The group from our Exchange who visited your place on Wednesday, the 23 rd, certainly returned home with a much keener appreciation of the splendid work that the Funk Bros. Farms are doing and have done in the past toward building up the highest type of corn which is of the most practical benefit to the producer, stock feeder and manufacturer. 


\section{BUSHELS OR MORE FOR 3 CENTS}

BY TREATING SEED COR.N

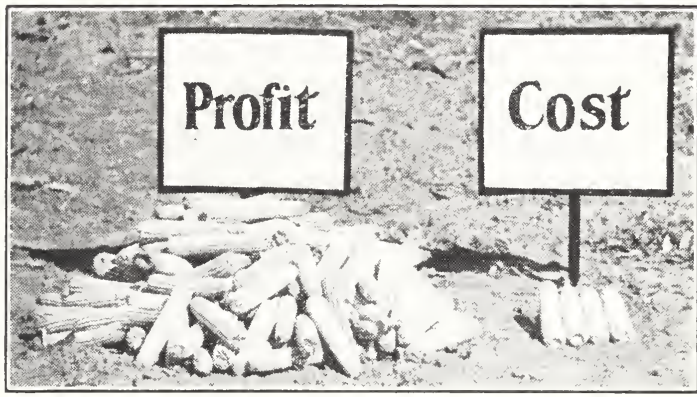

The four ears of corn represent the small cost of producing the added profits of 3 bushels per acre.

Three bushels or more corn can reasonably be expected by any farmer who treats seed corn before planting, Illinois Experiment Station tests show.

" Some very striking increases in stand, vigor, and yield of grain have been obtained from seed treatment. Even with the very best seed obtainable seed treatment, in Illinois experiments, has usually proved worth while. Some of the same treatments that have proved beneficial on dent corn, when applied to sweet corn seed, have been found to cause a substantial increase in the yield of prime canning corn.' '-University of Illinois, Circular 364.

Field or sweet seed corn dusted with Semesan $\mathrm{Jr}$. is protected from the destructive Diplodia, Gibberella, and Basisporium root rots carried by the seed and from rotting in cold, wet soil, consequently better germination, stands, and yields of improved quality are obtained.

Treatment with Semesan Jr. or Barbak III COSTS LESS THAN 3c PER ACRE AND PAYS A SPLENDID PROFIT on the cost. Easily and quickly applied as a dust at the rate of 2 ounces per bushel of seed.

Prices: 4 oz., \$.50; 1 lb., \$1.75; 5 lbs., \$8.00; 25 lbs., \$31.25. Free pamphlet. 


\section{Funk Farms Corn Show at Corn Plots Next Fall}

\section{Cash and Prizes Valued From $\$ 200.00$ to $\$ 500.00$, Depending on Interest Shown}

GRAND CHAMPION 10 EARS TO BE AWARD $\$$ D \$50.00 AND VALUABLE TROPHY. Competent disinterested judges. Entries limited to corn grown lrom FUNKS SEED in 1932. Entry blank with each order of 1 bushel or over.

\section{FIVE CLASSES}

Funks Hybrid-Funks Yellow Dent, Strain 176A-Funks 329, 100 Day Yellow Dent Funks 90 Day Yellow Dent-Silvermine

Win a valuable prize. Everyone has a chance. One entry to each class. Enter as many classes as you wish. A contest of any sort may be good sport, but here you have a chance to win a valuable prize for your efforts. Tell your friends and neighbors and have a little competition in your own locality to see who can produce the best corn from FUNKS SEED. You have all to gain and nothing to lose. Put forth your best corn growing efforts and try for a winner in this show.

\section{FUNK FARMS VISITORS}

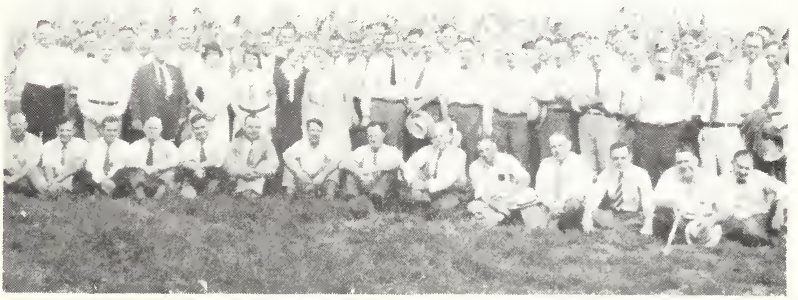

Farm advisers and farm managers

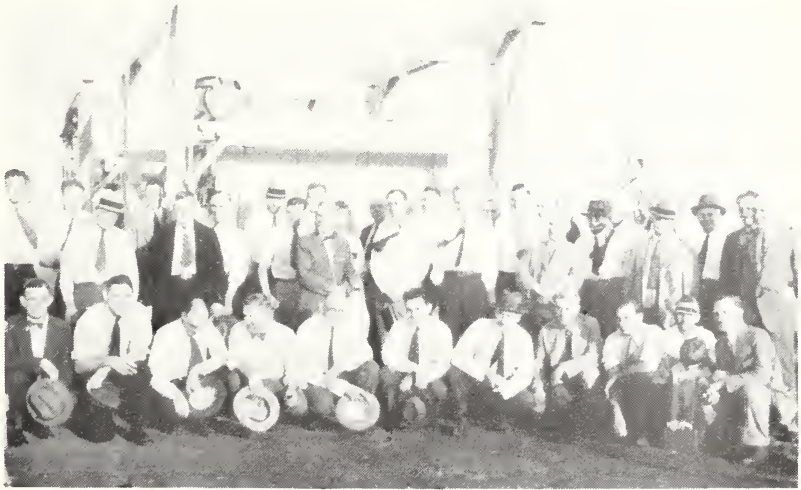

Grain members, Chicago Board of Trade visiting experimental plots on the Funk Farms

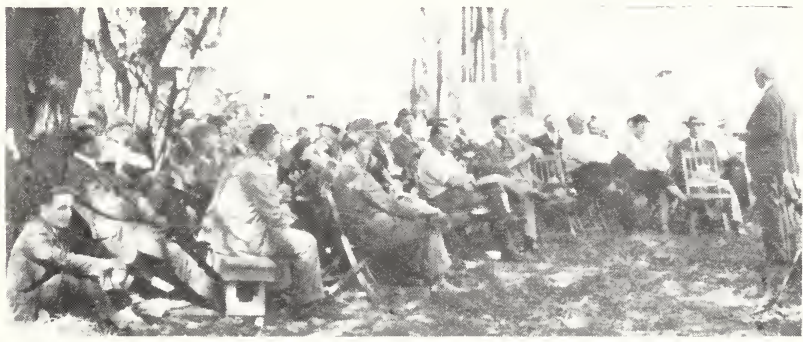

Mr. Funk welcomes our visitors

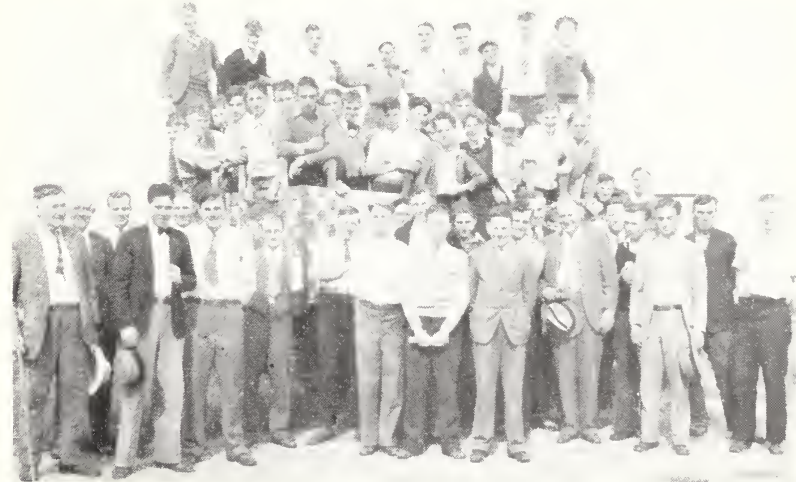

Sangamon County 4-H Club Boys

We are always glad to welcome America's future farmers 


\section{Profit in Legumes}

BETTER CORN YIELDS FOLLOWING LEGUMES

The soil-building possibilities of the hay crop in a rotation is clearly demonstrated by results reported in the 1931 Annual Report of the Illinois Agricultural Experiment Station. Corn following timothy with one cutting of hay yielded 52.5 bushels an acre. Following a crop of soy bean hay the yield jumped to 67.7 bushels an acre. After a crop of red clover where two cuttings were removed, the corn yielded 69.4 bushels. The banner crop, however, was raised on land which had previously grown alfalfa from which three cuttings were removed. The corn yield following alfalfa was 73.4 bushels an acre. In addition, the same gradation in yield was reflected in the oat crop following the corn.

Alfalfa, clover, soy beans-LEGUMES-that tells the story. Isn't it a characteristic of the prosperous farms which are returning a high labor income that they have a high proportion of the land in profitable $L E$ GUME crops?

LEGUMES for hay-LEGUMES for pasture-LEGUMES for soil builders. Surely you must realize that LEGUMES are a double-profit crop. Double profit because they produce a cash income in their own right and, at the same time, build up a reserve in the soil which produces a profitable return in increased yields of succeeding crops.

FUNK FARMS LEGUME seeds are clean, bright and of good quality. They are adapted to Corn Belt conditions. In fact, we buy our seed with our own farm in mind. We ask none to use seed we would not use or consider profitable ourselves.

We know from years of experience as farmers, and Experiment Station results bear out this experience, that LEGUMES are the most profitable crop on the farm. It is our firm conviction that LEGUMES are double-profit crops.

We welcome the opportunity to extend our experience, first as farmers and then as seedsmen, to your farm. An order blank and envelope are enclosed for your convenience. 


\section{NOCULATION}

Nodules on the Roots-Increased Yields Added Fertility-Lower Cost of Production

\section{GREATER PROFIT}

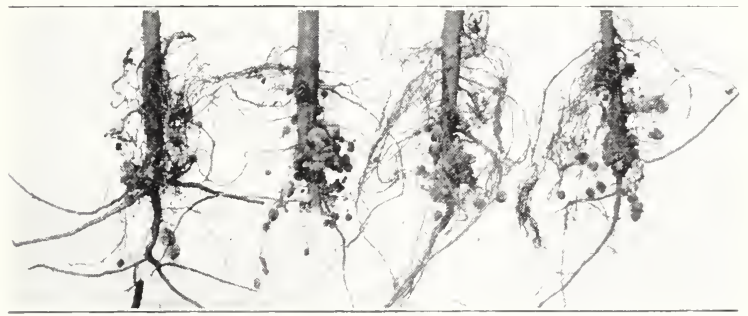

Legumes use nitrogen taken from the air by bacteria in the nodules on the roots.

\section{LIME NEEDED ON SOUR SOIL}

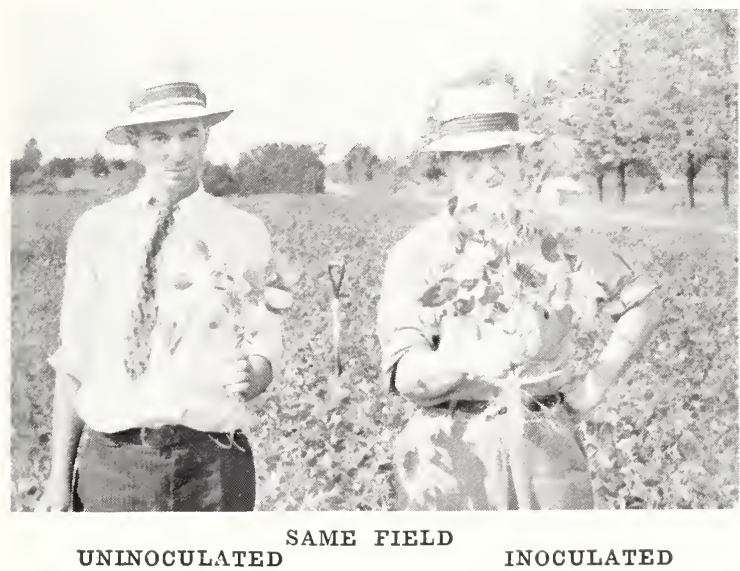

This field was sour and needed four tons of limestone per acre, except for strip on the right which had been limed by dust blown from limestone road. Note the difference in the growth of Soy Beans. Plant on right had many nodules while plant on left had none. Nodules are essential for best results with legumes.

Every Cent for Inoculation Makes a Dollar Profit 


\section{ALFALFA}

\section{DOUBLE PROFIT - FORAGE AND FERTILITY}

Success with Alfalfa is more dependent on soil conditions than on any other one factor. Sow Alfalfa inoculated with a good culture on well drained soil free from acidity and you are well on the road to Alfalfa success.

\section{SELECT A HARDY STRAIN OF ALFALFA}

Dakota 12

"Bee Hive", Hardy Utah Montana

Northwestern
A. B. Lyman Grimm (Montana Grown) Michigan Variegated State Sealed Grimm

A Hardy Strain of Alfalfa is an absolute essential for the maintenance of a good stand of Alfalfa over a period of years. We know this from our own experience on the Funk Farms. In fact, we secure Alfalfa with our own farms in mind. We ask none to use seed we would not use or consider profitable ourselves.

\section{RESEEDING OFTEN PROFITABLE}

During the past extremely dry season the Alfalfa patch was of ten the only green spot on the farm. Treat these Alfalfa patches properly. They have gone through a hard season. Many of them will respond to reseeding. Think the matter over carefully before plowing up an Alfalfa field which is still in fair shape.

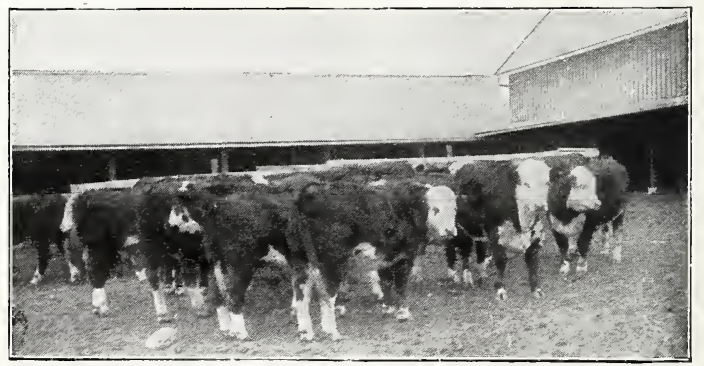

Alfalfa Hay is considered one of the most profitable crops on the Funk Farms. These steers made a fine gain on Alfalfa Hay, Soy Bean Oil Meal and Corn.

\section{U. S. GOV'T VERIFIFS ORIGIN OF ALL OUR ALFALFA}

We buy ALFALFA for you the same as though we intended to seed it on the FUNK FARMS. Quality, freedom from weeds, hardiness, germination and origin are prime considerations in our selection. 


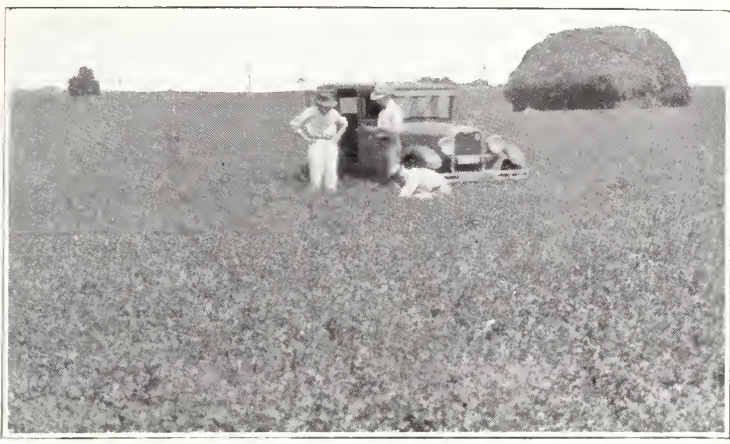

Mr. Frank I. Mann (at the left) is an enthusiastic Alfalfa booster. This is a field of "Bee Hive", Hardy Utah Alfalfa on his farm near Gilman, Illinois.

\section{Genuine Grimm Alfalfa} Montana Grown

Direct from A. B. Lyman, the father of this hardy variety, who discovered Grimm Alfalfa in 1890.

Practically all Grimm Alfalfa in America traces back to A. B. Lyman's Original Seed.

Mr. A. Lyman spent his entire effort upon improving this Alfalfa to its greatest hardiness.

This seed is hardy, winter proof, and enduring.

Put up in 1 bu. sealed bags and delivered to you in the original package.

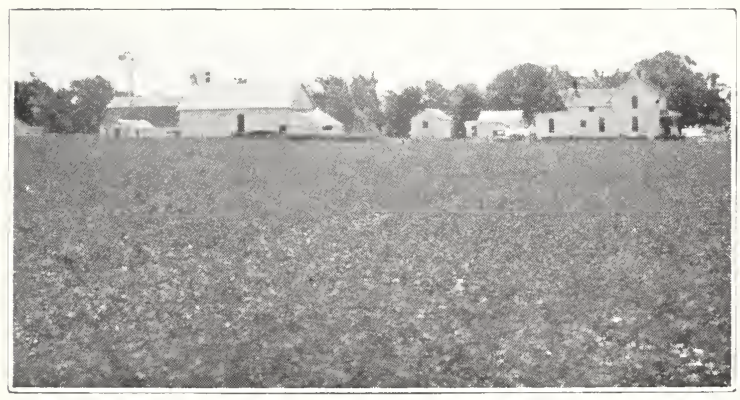

ALFALFA-PROSPERITY

This fine field of Alfalfa has probably contributed something to the fine farmstead in the background. The soil is neutral and the roots are full of nodules.

SEE FREE HYBRID SEED CORN OFFER ON PAGE 6. 


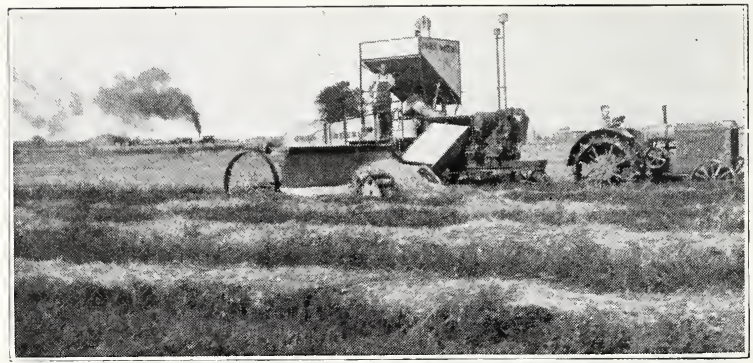

Note heavy stand of Sweet Clover in this wheat stubble on the Funk Farms. It will pay profits immediately as a rich pasture and later as increased corn yields.

\section{White Blossom Sweet Clover}

Sweet Clover is just as choicy as to soil as Alfalfa. It demands a soil free from acidity. A little time spent getting a soil test may save you considerable in seed and labor cost.

\section{INCREASES SOIL FERTILITY}

This crop has done much to increase the fertility of Illinois soils. This is due principally to the fact that such a large percentage of this crop is plowed under each year. It adds nitrogen to the soil. Its deep rooting habit enables it to feed on subsoil minerals which are plowed down into the surface soil. Sweet Clover also exerts a favorable action on the microorganism population of the soil. These are all causative factors in the beneficial influence of Sweet Clover on succeeding crops.

\section{PROFITABLE PASTURE}

Sweet Clover furnishes an excellent pasture. It furnishes good forage during late July and August. All stock thrives on it and soon learn to like it. Sweet Clover has a feeding value nearly equal to Alfalfa.

Sweet Clover merits a place on your farm if the soil is sweet or has been limed to neutralize acidity.

\section{Hubam Sweet Clover}

An annual Sweet Clover. Finds greatest usage seeded in oats or other spring grain to be plowed under for wheat that fall. This is an excellent way of introducing another legume into the rotation. 


\section{PURITY AND GERMINATION WITH EVERY BAG}

For your protection every bag of seed we sell carries a tag which gives the purity and germination. This is especially important to the purchaser who is not intimately acquainted with the various grades of seed.

Every seed buyer is entitled to know exactly what he is buying. Properly tagged seed furnishes you with this information. Demand the purity and germination no matter where you buy.

FUNK FARMS SEEDS give results. The germination is high. Our seed is selected for freedom from noxious weeds. Make certain you get the quality seed you pay for. After all it is performance you want.

The enclosed order blank will bring seed to your station without delay. And further, it will be seed of quality and value in line with the price you are charged for it. USE FUNK FARMS SEEDS.

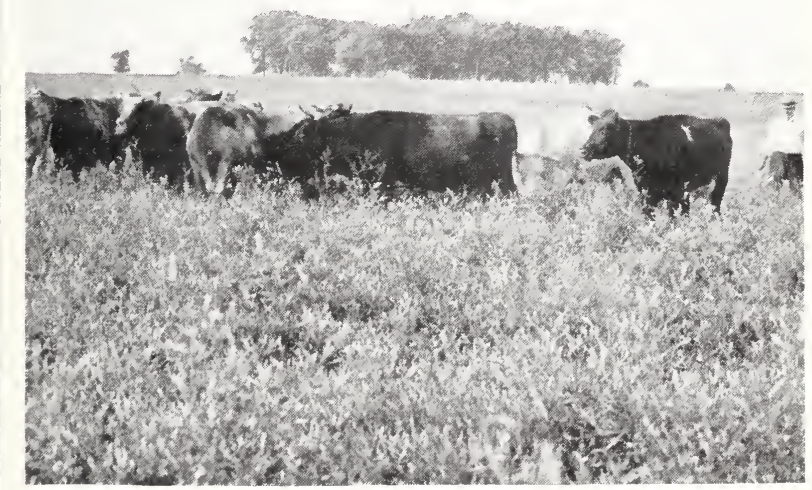

Grundy County Sweet Clover will provide a profitable pasture. The following crops will benefit from the added fertility. Legumes are double-profit crops.

\section{Grundy County Sweet Clover}

This is a white blossom variety which takes its name from Grundy County in Northern Illinois where it originated. It is a biennial and grows to a height of about four feet. Never to our knowledge has it been known to winter kill.

Grundy County Sweet Clover is a fine soil builder, a heavy seed producer, ripens ahead of most weeds. 


\section{SOY BEANS}

A utility cash crop-hay, seed and soil improvement -adapted to Corn Belt conditions-Permanent future assured-average record for profit good.

Soy Beans fit into existing rotations very easily. They can replace other legume crops at a moment's notice or substitute for a crop which has winter killed. They can be harvested for grain or hay or turned under for a green manure. We carry a very complete line of varieties adapted to Corn Belt conditions. Write us regarding your needs.

\section{FEED FUNKS SOY BEAN OIL MEAL}

Among the advantages in feeding Funks Soy Bean Oil Meal are:

1. Soy Bean Oil Meal contains approximately $5 \%$ more protein than Soy Beans.

2. Soy Bean Oil Meal has a bland, nut like flavor, highly palatable and greatly relished by all livestock.

3. Soy Bean Oil Meal can be fed without danger of producing soft pork.

4. Soy Bean Oil Meal can be fed economically for maximum production, to dairy cows, beef cattle, hogs, poultry and sheep and pound for pound in place of oil meals in their ration.

5. Cooked and toasted meal. In the course of milling beans are subjected to very high temperatures. This cooking materially increases the feeding value. The Ohio Experiment Station has found that by cooking Soy Beans at high temperatures the feeding value was enhanced and Soy Bean Oil Meal, having been cooked, has more feeding value than raw beans.

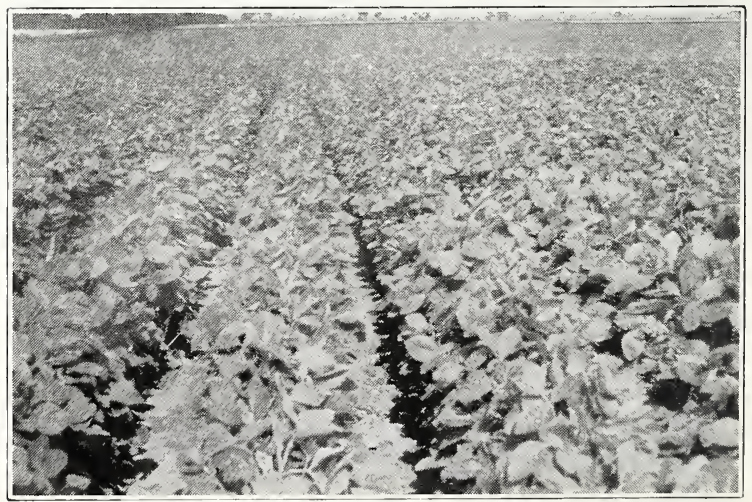

A part of hundreds of acres of Soy Beans on the Funk Farms. Experiment Station data show that corn following a crop of Soy Bean hay yielded 15.2 bushels an acre more than corn following a crop of timothy hay.

SEE FREE HYBRID SEED CORN OFFER ON PAGE 6. 


\section{Funk's Soy Bean Hay Mixture}

Makes a sure shot hay crop and meets the demand for a high quality hay. It can be planted in the spring after corn planting and be ready for fall harvest. No other legume hay can meet these requirements and maintain the high quality demanded by the successful farmer. Two bushels per acre seeded in the spring returns up to 4 ton of hay in the fall.

The hay mixture is made up of hay varieties such as Ebony, Virginia and Wilson, with sufficient early maturing yellow varieties to permit cutting so that a proper balance of leaves and grain are obtained. The stiffer strawed early varieties also aid in preventing lodging and the hay is more easily cured.

Use this hay mixture where other legume hay crops have failed to survive the winter. It is profitable as a corn field border for a turn row. Drill the beans in after the second cultivation and utilize the field edge most efficiently.

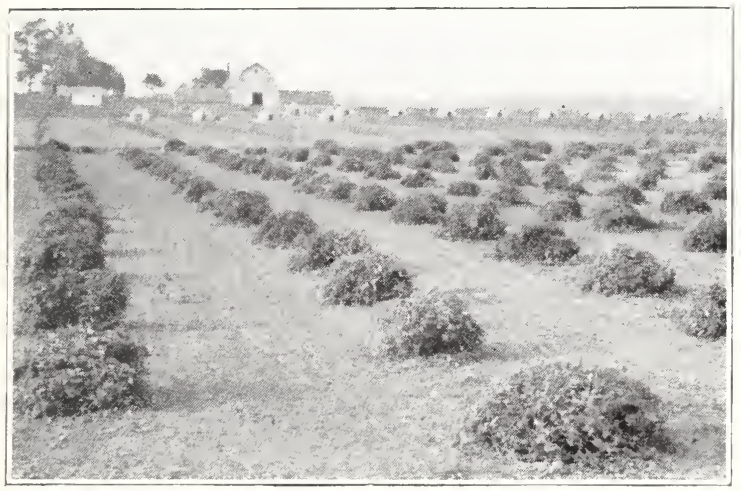

Soy Bean hay cocked for curing. High quaity legume hay on short notice.

FUNK FARMS BRAND SOY BEANS are high germinating, clean, pure seed. Being farmers as well as seedsmen we know the value of quality seed and the additional profit that can be realized because of good seed. Our seed stock is the cream of the Illinois crop and is yours for less money, quality grading and purity considered, than any other beans you can buy. Orders will be booked for spring delivery. Reserve your requirements at an early date. 


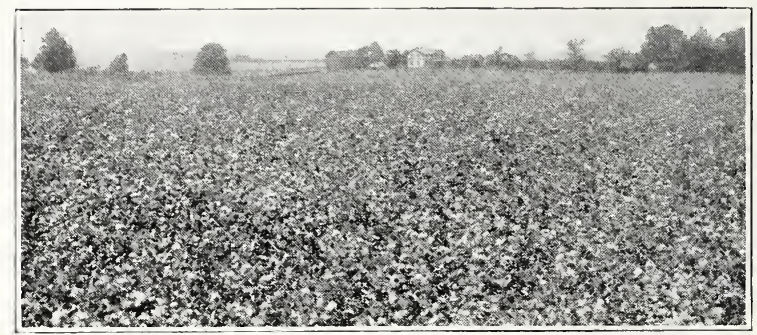

Red Clover will grow on slightly acid soil. Fields such as this mean a gcod supply of hay or pasture and increased soil fertility.

\section{RED CLOVER}

A field of Red Clover is a profitable crop and the quality of the seed you plant should be given every consideration not only for the sake of yield, but to produce a crop free from noxious weeds.

The 1930 Annual Report of the Illinois station reports results of recent Red Clover investigations. An important finding is that fall clipping about September 1st raised seed yields about 25 percent and hay yields about 20 percent.

Seeding the latter part of March gave a better stand than seedings a month later.

Spring clipping the second year is not recommended for seed production. It is also stated that the first crop gives a slightly higher seed yield where it is not needed. for hay.

We can supply you with either home grown or Idaho seed. Both are high quality and clean. Let us figure with you regarding your needs this spring.

\section{ALSIKE CLOVER}

Alsike is a perennial and therefore fits into permanent pastures somewhat better than Red Clover. It also tolerates a bit more soil acidity and survives in low spots where other legumes fail. Be sure Alsike is included in the pasture mixture you use on low land. Most commonly used with Timothy for hay and pasture, Alsike works into practically all hay and pasture mixtures with success. 


\section{Korean Lespedeza}

\section{THIN LAND LEGUME}

A more recently introduced legume which is adapted to thin sour land. It differs from the Lespedeza commonly grown in the south in that it is about two weeks earlier and it starts growing earlier in the spring.

The Illinois Agricultural Experiment Station reports good success with it in Southern Illinois. It should be seeded early in the spring, using 10 to $12 \mathrm{lbs}$. of seed to the acre after the oats are in.

Reports from Southern Illinois indicate that it is very acid tolerant, growing on soils with a five ton lime requirement. It is a good pasture and hay crop and readily reseeds itself even after hay has been cut from it.

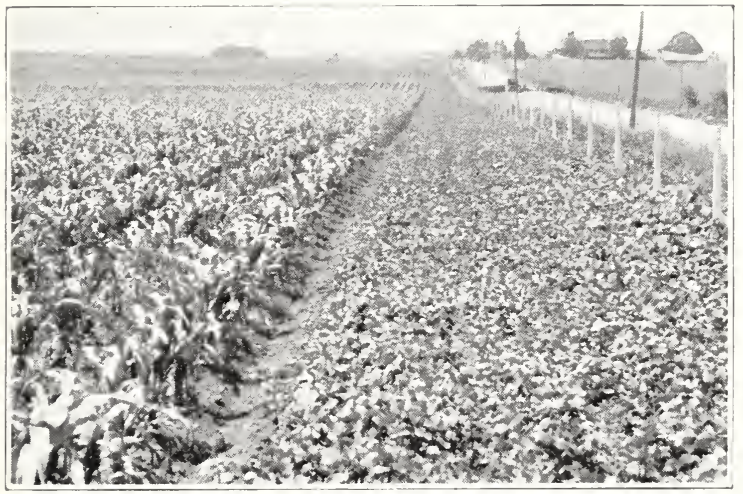

\section{A SOY BEAN TURN ROW}

Just the place to use Funk's Soy Bean Hay Mixture. Such a turn row makes for more efficient land utilization. This practice has been used successfully on the Funk Farms for several years.

\section{Mammoth Clover}

Big English

Mammoth Clover is similar to red clover both in appearance of seed and in habit of growth. It is later maturing and grows larger than red clover and for that reason is superior for a soil improvement crop. It is well adapted to use on thin soils. Mammoth Clover is a good variety to seed with Timothy since both mature at about the same time. Sow 8 to 10 pounds per acre by itself or 6 pounds of Mammoth Clover and 8 pounds of Timothy per acre makes a good mixture. 17. 


\section{Lower Oats Cost By Increasing Acre Yields}

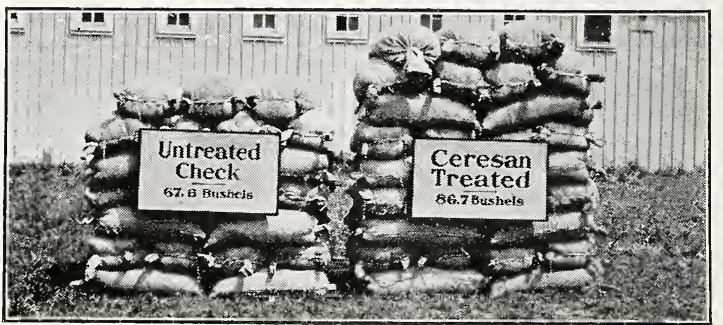

Ceresan increased the yield of oats 19.1 bushels per acre in Illinois Experiment Station tests.

Lower your oats production cost per acre-enlarge your profits-by increasing yields with Ceresan. Treat all seed oats with Ceresan to prevent seed-borne smuts and scab seedling blights. Through controlling these diseases Ceresan increases the yields and quality.

The table from the 1930-31 Annual Report of the Illinois Experiment Station shows conclusively that Oat treatment pays.

Effect of Certain Seed Treatments on Two Varieties of Oats, Three Year Average, 1928-1930.

Seed Treatment Smut Yield per ct. bu. NONE ...................... $6.09 \quad 68.0$

Formaldehyde (liquid) $\ldots \ldots \ldots \ldots \ldots 00,72.8$ Formaldehyde (dry) . . . . . . . . . . . 31 74.9 Ethyl-mercury-chloride (Ceresan) $\ldots . .07 \quad .07 \quad 80.1$

Dust it on the seed before planting-no soaking or wetting of the seed-no injury to the seed. Economical to use. Apply 3 ounces per bushel of seed oats and barley; and 2 ounces for wheat, rye, or sorghums.

Prices: 1 lb., \$.75; 5 lbs., \$3.00; 25 lbs., \$12.50; 100 lbs., $\$ 49.00$. Free pamphlet.

\section{CERESAN FOR SMALL GRAINS}

\section{OATS}

Heavy oats of good seed quality are going to sell at a premium this spring. We can supply you with the bright, heavy, high germinating seed you are looking for.

FUNKS great American, Silvermine, Big Four, Iowar, Iowa 103 and Gopher are the standard varieties you will want to select from. They are all good yielders.

Take advantage of the nice increase in yield you can obtain by the use of CERESAN on your seed oats. Increased yields mean lower cost of production. Here is an easy and immediate way to greater profits from oats. 


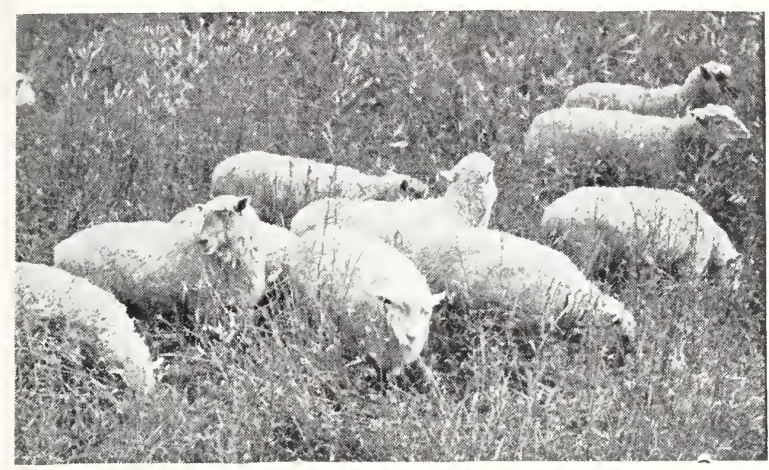

Seed a LEGUME in every acre of small grain. Insure your soil fertility. Future profit will depend on a low cost of production. The price of Alfalfa, Clover, Sweet Clover, etc., is very favorable this spring.

\section{BARLEY}

\section{WE RECOMMEND WISCONSIN PEDIGREE 37 SCAB RESISTANT}

The 1931 Annual Report of the Illinois Agricultural Experiment Station reports as follows:

"Having outyielded other varieties, Wisconsin Pedigree 37 has demonstrated that it is a good choice for the BARLEY grower of Illinois. It outyielded the nearest variety by 3 bushels an acre on the DeKalb field and by 4 bushels an acre at Urbana. At the same time it produced grain of high quality.'

Barley is considered the best nurse crop for spring seeded clover and alfalfa. The grain makes an excellent stock feed. Should you desire to sell on the market there is always the possibility of a premium for a malting and pearling type grain. Wisconsin 37 is reported to be suitable for this trade.

Don't forget that Ceresan applied to barley pays a good return on the investment. Our seed supply of Wisconsin 37 was grown on the FUNK FARMS. Use enclosed order blank for both Barley and Ceresan.

\section{SPRING WHEAT}

Illinois No. 1 is one of five varieties of spring wheat which is outyielding Marquis according to reports from the Illinois Agricultural Experiment Station. This is the most scab resistant variety adapted to Illinois conditions. We have the high quality seed of Illinois No. 1 which is the start of a good crop.

The Illinois Experiment Station reports that seed treatment is responsible for a ten bushel increase in the yield of wheat. Cut your acre cost by utilizing this easy means to more bushels per acre. Order CERESAN for your wheat. 


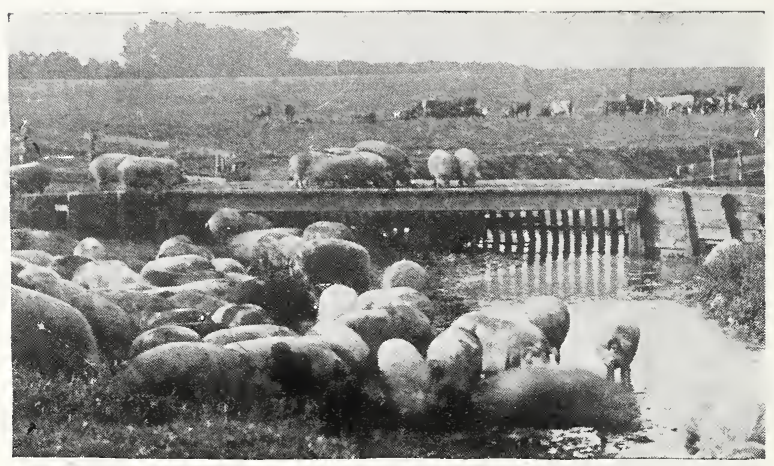

A creek pasture on the Funk Farms. All farm animals thrive economically on good pasture. Prices are favorable for seeding new pastures and reseeding old ones.

\section{RED TOP}

You will be surprised what it will yield on land you consider worthless. During the past exceedingly dry season it produced well. It is also adapted to poorly drained soils.

\section{TIMOTHY}

Produces a hay of good quality. An almost certain catch on most soils. A good stand will last several years.

\section{SUDAN GRASS}

A great quantity of hay can be secured in a very short time from Sudan. Two cuttings are recommended and often three can be obtained. It is best to cut before it gets too tall and rank.

Easily as good a hay as Timothy and relished by all livestock. Makes a sure summer pasture. Works well in pasture mixtures.

Sow 15 to $25 \mathrm{lbs}$. per acre about May 20th after all danger of frost is past.

\section{R APE}

\section{HOLLAND GROWN DWARF ESSEX}

Recommended for Hog Pasture. Seeded with oats it provides a good summer pasture. For early pasture seed with oats and pasture oats early and rape later.

Rape is good for hogs, sheep, cattle, and horses. It is easily grown, furnishes a quick pasture and lasts from about June to November. The most successful raisers recommend a slightly heavier seeding rate than is generally used.

Sow five to eight pounds per acre or three to four pounds when sown in corn at last cultivation. 


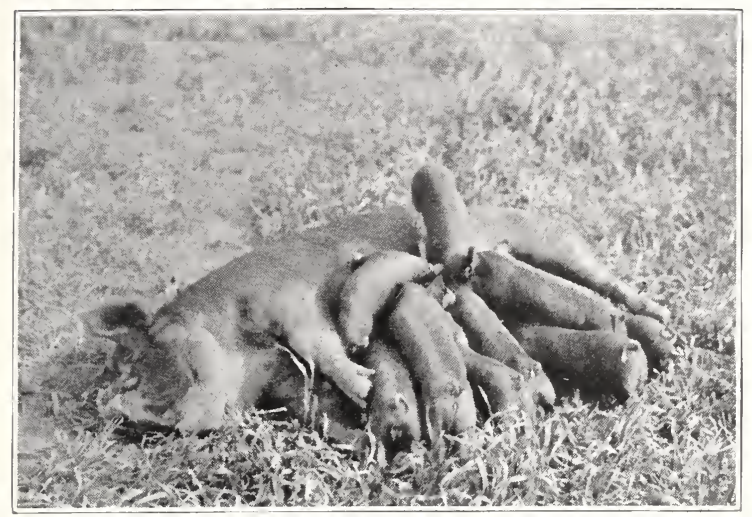

Clean forage is essential for economical animal husbandry. Build profits with paying pastures.

\section{THE OLD STANDBY}

Now is the Most Favorable Time in TWENTY.FIVE YEARS to Start a Good Old Fashioned Kentucky Blue Grass Pasture

Kentucky Blue Grass is the basis of all permanent pastures. As you know, Blue Grass is extremely hardy, coming through even our severest winters. Nor does it seem to matter how dry the summer gets; Blue Grass stands the drought and, with the next rain, comes on with renewed vigor.

\section{BLUE GRASS PRICES ARE LOWER}

The price has been so high in recent years that nearly the entire crop was used for lawns and golf courses. This year you can afford to use Kentucky Blue Grass for pasture purposes because the price is low.

Pick out a piece of ground as close to your buildings as possible and seed it down this spring with our PERMANENT PASTURE MIXTURE.

\section{MIXTURE MOSTLY BLUE GRASS}

\section{SEED 15-18 LBS. PER ACRE}

Fifty percent of this mixture is high grade Kentucky Blue Grass. The balance is made up of Red Top, Fescue, Rye Grass and Timothy. These grasses establish themselves more quickly than Kentucky Blue Grass but eventually the Blue Grass will crowd them out.

There is too much of our land devoted to grain crops and now every farmer has an opportunity of turning a few acres of this crop land into a permanent pasture which provides abundant, luxuriant forage throughout the season.

\section{OTHER MIXTURES}

Should you desire a pasture mixture containing alfalfa, red clover, alsike or a quick growth annual hog pasture write us regarding your requirements and we will make up a mixture which will suit your purpose. 


\section{DRAIN YOUR MUD HOLES}

Stop Unnecessary Loss From Drowning Out in Ponds and Low Spots

USE

Funks Field and Road Drain

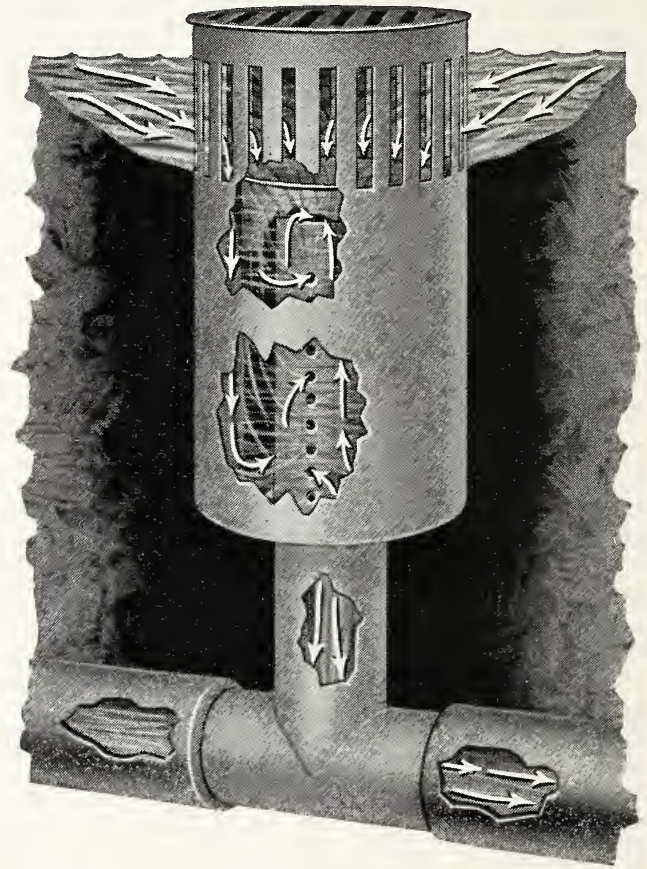

Take the excess water away from the surface of PONDS and LOW SPOTS in your fields before there is a loss by drowning out. This drain diverts the water directly into the tile. It puts your LOW LAND into shape to be worked with the rest of the land in the spring. MUD HOLES should be a thing of the past.

Winter killing is lessened by immediate removal of water from winter rains or from melting snow. Taxes are assessed against all the land. It is up to you to make a profit from all the land.

\section{A Drain Pays for Itself in One Season}




\section{Funks Soy Bean Oil Meal}

AVERAGE ANALYSES

Composition Digestibility

Protein .............41\%........ 92\%

Fat $\ldots \ldots \ldots \ldots \ldots \ldots \ldots \ldots .6 . \ldots \ldots \%$

Nitrogen Free Extract.... 27\% .........100\%

Crude Fiber .......... $7 \% \ldots \ldots \ldots . . \ldots 9 \%$

SOY BEAN OIL MEAL is manufactured from a home grown product. It has been used successfully with all classes of live stock. Excellent results have been obtained. Write for prices and stock feeding circular.

\section{Soy Bean Flour}

Soy Bean Flour is becoming more and more popular as the public is slowly realizing its value in the diet. It may be blended with other flours or used alone. Diabetics particularly find it a valuable low carbohydrate food.

We have been making Soy Bean Flour for years and have a number of regular repeat customers for this item. Write for prices and receipts.

Funks Soy Bean Oil Mill at Taylorville, Illinois Outside Cover Page Shows Mill at Bloomington

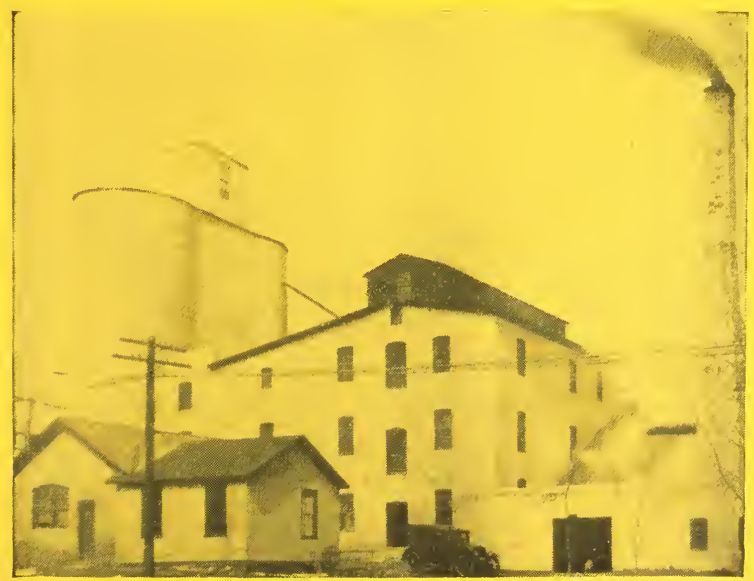

A COMPLETE LINE OF FARM SEEDS FOR SALF AT OUR TAYLORVILLE BRANCH PLANT 


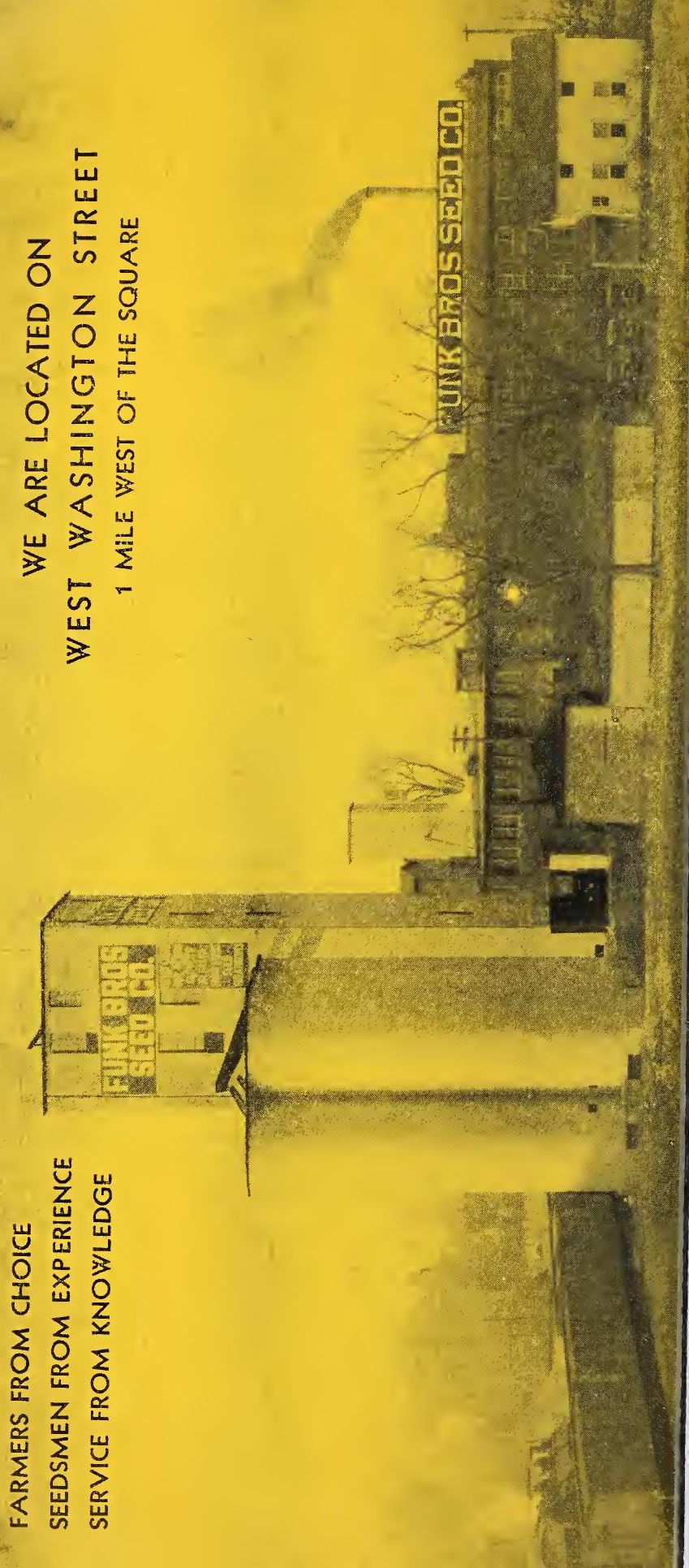

